\title{
ロバストモーションコントロールにおける 力制御と環境認識*
}

\author{
村上俊之**
}

Force Control and Environmental Recognition in Robust Motion Control / Toshiyuki MURAKAMI

Key words: robust motion control, force control, environment, force estimation

\section{1.は じめに}

1967 年，ロボットが工場での溶接や塗装用の産業口 ボットとして導入されて以来, 国内におけるロボット開発 は急速に進められ，近年では産業用としてだけではなく， 一般家庭でのアミューズメント機器あるいは介護機器とし ての利用が強く期待されている. 産業界において求められ ていたロボットの機能は, 位置制御をベースとした高速, 高精度, 高効率, 高信頼性であった. これらの要求は, 七 ンサ, コンピュータの急速な発展とロバストモーションコ ントロール, メカトロニクス技術の発展と相まって問題な く達成され, 多くの産業分野におけるロボット導入をもた らした ${ }^{1}$. しかしながら, 大量生産から変種変量生産への 需要変化, また高齢化社会に向けた福祉機器の開発要求か ら, 環境適応型のロボットや人間の五感に作用するア ミューズメントロボット等の実現に多くの関心が寄せられ るようになってきた。このような要求に応えるためには, 従来型の位置制御をべースとしたロバストなモーションコ ントロールのみではなく, 環境変動に適応可能な力情報に 基づいたロボット制御の機能拡張が必要となる. 力情報に 基づいたカフィードバック制御に関してはすでに多くの研 究報告がなされているが2), 力情報に含まれる環境情報を 考慮した制御アルゴリズムや力を利用した環境適応型制御 に関する研究報告例は少ない ${ }^{3)}$. 一方, 力情報は人間や口 ボットのような機械システムを含むシステム間の相互作用 を決定するものであり, ロボット間の協調はいうまでもな く, 人間とロボット間の協調動作を円滑なものとするのに 力（相互作用力）は有用な情報となり得る. ただし, 力制

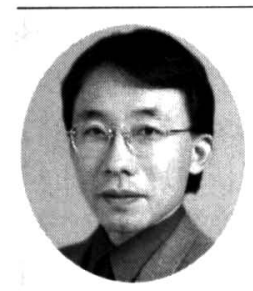

* 原稿受付 平成 15 年 8 月 14 日

** 慶應義塾大学理工学部（横浜市港北区日吉 $3-$ 14-1)

1993 年 3 月慶應義熟大学大学院後期博士課程 修了, 博士 (工学). 現在, 慶應義熟大学理工 学部システムデザイン工学科助教授. 七ンサ応 用システム，モーションコントロールなどの研 究に従事.
御は位置制御に基づいたロバストコントロールからみる と，そのロバスト性（頑健性）を低下させることになり， 制御の目的に応じた適切な力制御系の構成を考える必要が ある. そこで本稿では, 力情報に基ついたロボットの機能 拡張 (多機能化), さらにロボットと人間の協調を目指し た協調制御手法について紹介する.

従来, 力情報を利用した力フィードバック制御では力セ ンサを利用したものがほとんどである. しかしながら，力 センサの利用はその取り付け位置やコストの面から必ずし も便利ではない. しかも, 力センサのない部位での力制御 は実現し得ない. そこで，本稿では上記の力情報に基づい たロボットシステムの多機能化に加え, 力センサを用いず に推定反力情報を利用した拡張機能についても紹介する.

\section{2. 力情報を利用したシステム制御}

先に述べたように, 大量生産を目的とした産業ロボット の導入では, 高速, 高精度, 高効率を目指したロボット制 御が主体となり，特に位置制御をベースとした制御手法が 考えられていた.これは，図1に示されるように，ロ ボットの内界センサを利用した制御となり外部環境の変化 は外乱として抑圧し，できるだけ位置指令に忠実に従う制 御となっていた。この場合, 環境変動に対して適応的な動

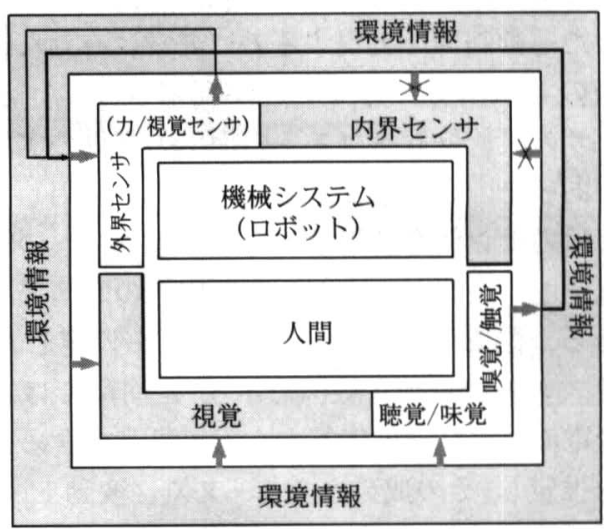

図 1 環境とシステム 


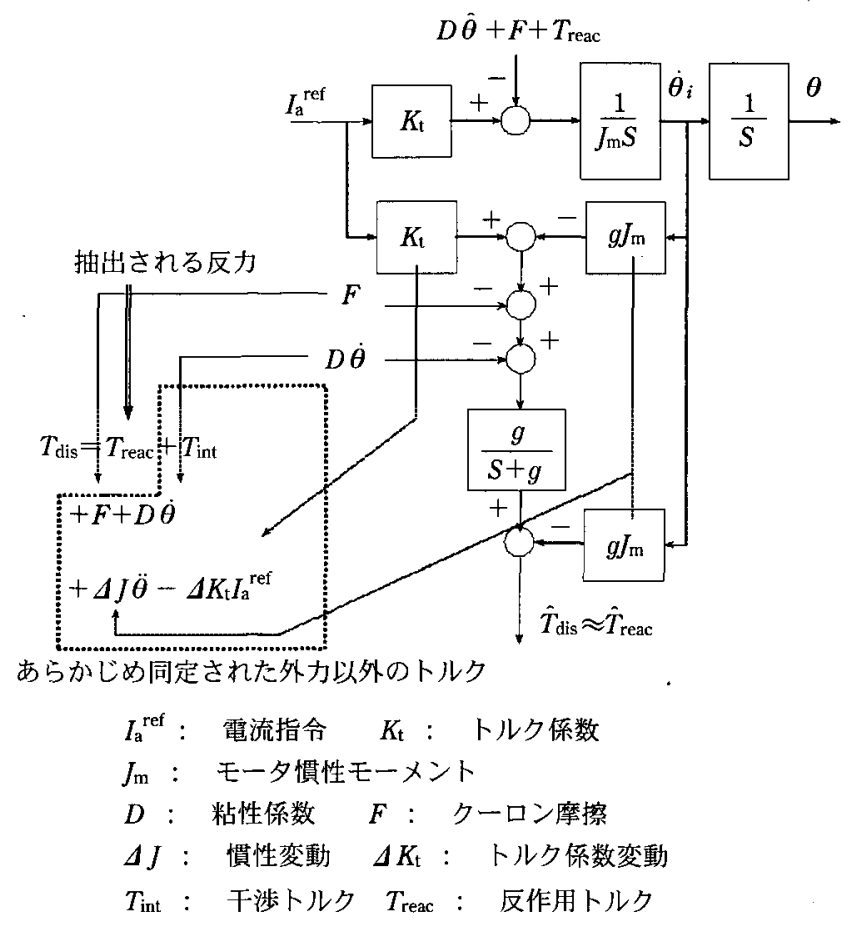

图 2 反力の推定アルゴリズム

作を䒠現することはきわめて困難である，従来，環境の認 識は非接触型の視覚センサや接触型のカセンサの利用が盛 んに行われていた．特に，人の環境認識の $80 \%$ は視覚情 報より得ているといわれて抢り，視覚センサを利用した環 境認識は有效なものと考えられる。しかしながら，認識速 度が十分に得られず，センサ情報の信賴性も低いことから 環境適応型の運動制御の実現には必ずしも適さない4)。一 方，力情報は接触を伴わなければ情報が得られないという 制約があり，得られる情報量も多くはないが，センサ情報 の信頼性は高く速い応答が要求される環境適応型の運動制 御には非常に有用である。 そこで, 本稿では力情報をべー スとした環境適応型の制御手法に関して幾つかの事例を紹 介する。

\section{3. 力の推定機構}

前述したように，力情報は環境変動を認識し，その変動 に適応した運動制御を実現するのに非常に有効な情報とな る. 従来の力検出では力センサが利用されている例が多 く，センサの設置位置やコストの面で力制御の実現に多く の制約があった。しかしながら，電動機を利用した機械シ ステムでは力センサを利用せずとも, 電動機への電流指令 と位置 (速度) 情報から力センサと同等の力情報を得るこ とができる. 図 2 に直流サーボモー夕を仮定した力推定 アルゴリズムのブロック線図を示す5). 同図では，モータ への指令電流および速度応答から環境外乱を含めたシステ 厶外乱を推定し,その成分からモー夕慣性変動卜ルク $\Delta J \ddot{\theta}$, トルク係数変動卜ルク $\Delta K_{\mathrm{t}} \mathrm{I}_{\mathrm{a}}^{\mathrm{ret}}$, 干涉トルク $T_{\mathrm{int}}$, 摩擦トル クを差し引くことによって反カトルク $T_{\text {reac }}$ のみを抽出す

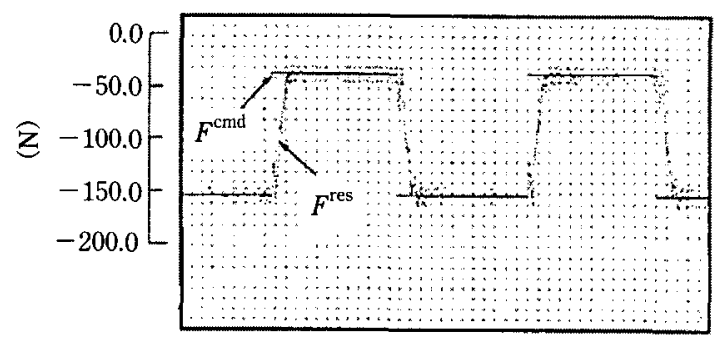

時間 $(40 \mathrm{~ms} / \mathrm{div})$

(a) 力指令および推定反力応答

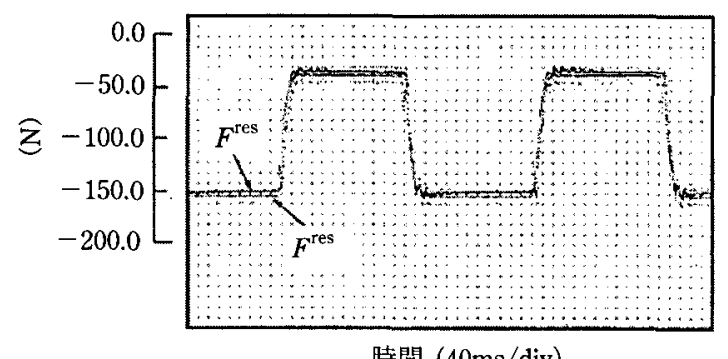

(b) カセンサ応答および推定反力応答

図 3 推定反力に基づいた力制御（奏験結果）

る計算過程を示している。また，推定反力を用いた多自由 度マニピュレータによるカフィードバック制御の実験結果 を図 3 に示す。実験では 3 自由度マニピュレータを用い て壁への押し作業 (力制御)を行っている。ここで, $F^{c m d}, F^{r e s}$ および $\hat{F}^{r s s}$ は力指令, センサの力応答, 反力推 定アルゴリズムによる反力推定值をおのおの表している. 同結果より推定反力によるカフィードバック制御でも， ， イズの影響で多少の変動（数 N）が見られるものの力セン サと同等の実験結果が得られて㧍り，反力推定アルゴリズ ムの妥当性がうかがえる. 同反力推定アルゴリズムを用い ることによって，カセンサの設置が困難なシステムにおい ても力制御が可能となり, 力制御の適用範囲拡張が期待で きる。

\section{4. 力情報をベースとした環境適応型制御}

前述した力推定アルゴリズムまたはカセンサをべースと した環境適応型制御手法として，複数台移動ロボットの負 荷分配制御，アクティブジョイスティックに基づいた電動 車椅子の制御，人支援型移動マニピュレータの制御につい て以下に紹介する。

\section{1 複数台移動ロボットの負荷分配制御}

移動ロボットの協調制御において，駆動輪に作用する負 荷情報は搬送物体の重量および走行路面の状態を知るうえ で有用な情報となる . 例えば，一つの搬送物体を複数台 の移動ロボットで安定に運搬するには，各移動ロボットに よる均等な負荷分配を実現する最適な把持位置の決定が必 要となる．图4（a）は２台の移動ロボットによる搬送制 御を示している.ここで，搬送物の重心は 2 台のロボット 


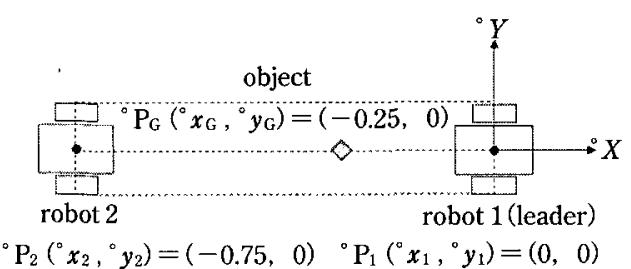

(a) 搬送状態のモデル

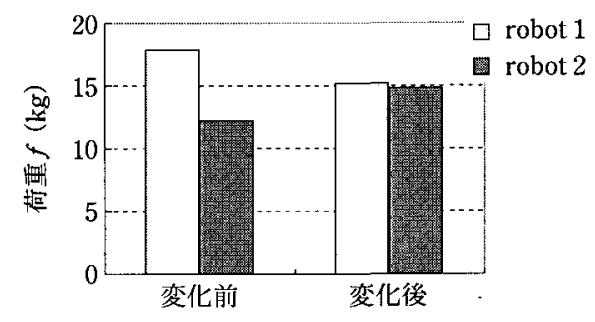

（b）負荷分配調整

図 4 負荷均等分配の実験例

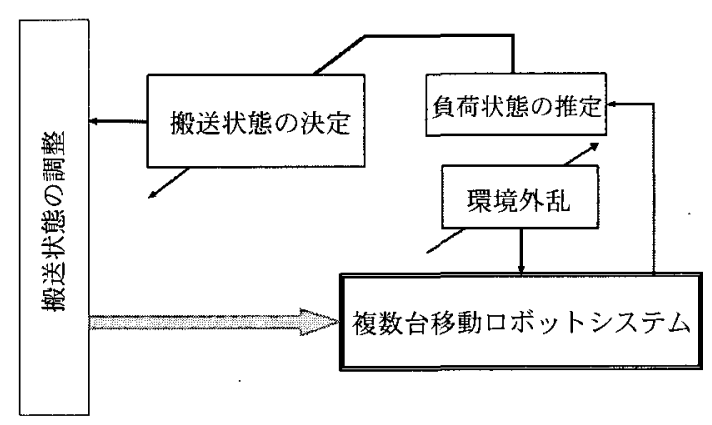

图 5 負荷状態推定に基ついた複数台移動ロボットの協調搬送制御

間の中心に設定されることが連搬の安定性確保の面から望 ましい，さらに，各移動ロボットの負荷としては路面から 受ける環境変動も考虑する必要がある。，そこで，図 2 のア ルゴリズムに基づき変動する環境外乱に応じた駆動軸に作 用する反力トルクを推定し，搬送物体の把持状態㧍よび走 行路面の状態変化を知ることによって，安定に搬送作業を 実現するための把持位置決定と負荷分配を考慮した搬送状 態制御を実現している（図 5)。図 4（b）に推定負荷情 報に基づいた把持位置決定による負荷均等分配の実験例を 示す. 同図より，推定反力情報に基づいた把持位置の変更 に伴って各移動ロボットへの負荷均等分配が適切に行われ ていることがわかる.

\section{2 アクティブジョイステックによる電動車椅子の制御} 高齢化社会に向けた工学的な対策として, 福祉機器の高 性能化が強く要求されている。こうした中で, 多機能化さ れた電動車椅子の実現は近未来の重要課題として着目され ている. 電動車椅子の制御では, 電動車椅子の自律生成軌 道制御と人のジョイスティック操作の融合によって操作者 の操作負担軽隇が期待できる。しかしながら，人の操作感 賞に違和感を与えないようにするため, 電動車椅子（移動 ロボット）の自律軌道と人の操作意思をうまく融合するこ

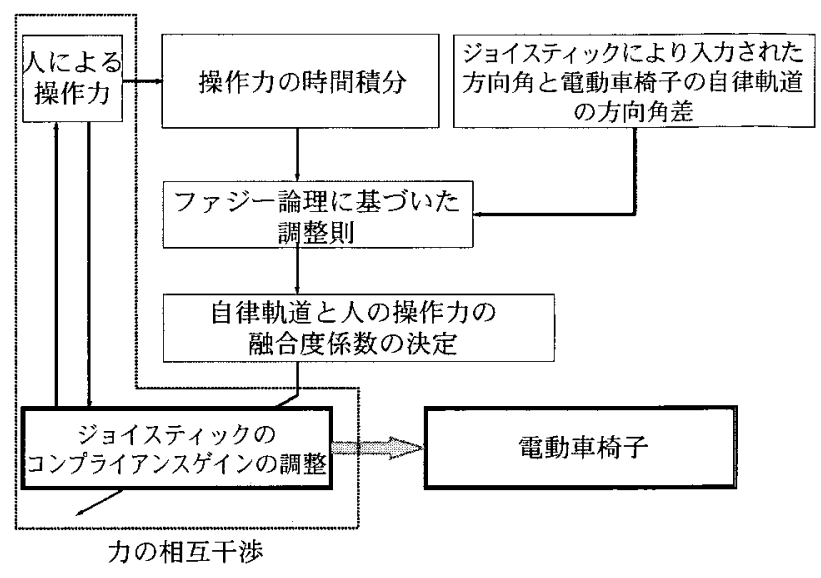

図 6 自律軌道制御と人操作の融合アルゴリズム

とが要求される.この融合においても力情報が重要な担い 手となる. 提案手法では図 6 に示されるように，人操作 による力入力の積分值执よび自律軌道と人操作による進行 方向の方向角差を入力とするファジー制御により，ジョイ ステックの操作性を決定するコンプライアンス制御系のゲ インが変化し, 自律生成軌道と人の操作意志の融合化がは かられている7).

\section{3 人支援型移動マニピュレータの制御}

高齢化社会に向けた福祉機器として，人の動作を支援す るロボットを考えた場合、広範囲な移動機能をもつ移動マ ニピュレータは非常に有用なものとなる. 移動マニピュ レータによる人の支援動作では, 人と移動マニピュレータ の相互作用力 (力情報) が安定かつ安全な協調動作を実現 するうえで重要な指標となる，そこで，提案手法では移動 マニピュレータへの操作力を力センサにより検出し, さら に検出された力を人と移動マニピュレータ間に設定された 仮想インピーダンスへの入力とすることで，人と移動マニ ピュレータの安定した協調動作を実現している（図 7). また，マニピュレータの特異点回避㧍よび台車の適度な移 動動作を実現するため，マニピュレータの操作性を考慮し た等価質量行列の調整を行うことで人の操作入力に対して 滑らかな動作応答を実現している ${ }^{8}$. 同制御では，移動マ ニピュレータは人の進行方向への操作入力に対し骬らかに 追従しつつ, 垂直方向に対しては人を支える動作が実現さ れており，移動マニピュレータは仮想的なつえの役割を 担っていることになる。また，图8に示すように，移動 マニピュレータへの動作指令を人の操作入力とは独立に与 えることで，人の動作を誘導する制御ともなる. 設定軌道 を追従している移動マニピュレー夕に，人操作による外力 を加えた場合のインピーダンス応答を図 9 に示す．同結 果では，移動マニピュレータの任意の軌道制御時に人によ る外力が加えられた場合の位置応答を示している。これに より，人の誘導支援を行っているマニピュレータ動作に対 して，力情報に基づいた任意の軌道修正が可能であること 

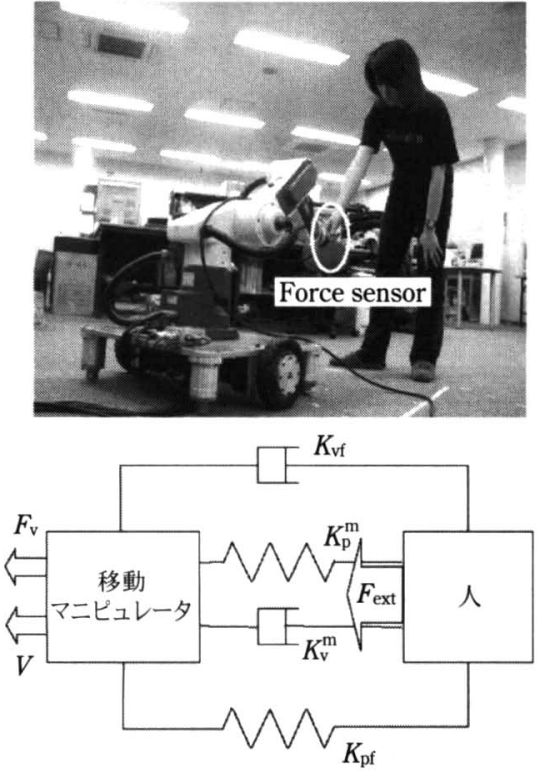

図 7 移動マニピュレータの人支援動作

がわかる.すなわち、マニピュレータと人の安定した干涉 動作が実現できていることがわかる.

\section{5. おわりに}

本稿では，力情報に基づいたロボットの機能拡張制御に ついて紹介した。ロボットに作用する反力情報は環境情報 をも含んで扔り，環境変動に対する適応動作を行うための 重要な指標もしくは動作指令生成のフィードバック信号と して活用できる．特に，ロボットと人との協調動作では, ロボットもしくは人の動作状態を双方に伝達するため, 力 情報は非常に有用であり福祉機器として関心が高まってい るロボットの多機能化に必要不可欠なものといえる.しか しながら，力情報のみによる環境適応型制御には限界があ り，非接触型の視覚センサやPSD による環境情報も融合 することで，環境変動に対してよりロバストな実用的運動 制御手法の実現が今後の課題となろう。

\section{参 考 文 献}

1) T. Murakami and K. Ohnishi: Advanced Motion Control in Mechatronics-A Tutorial, IEEE. Workshop on Intelligent Motion Control, 1, (SL) (1990) 9.

2) O. Khatib : A Unified Approach for Motion and Force Control of Robot Manipulators: The Operational Space Formulation, IEEE. J. of Robotics and Automation, RA-3, (1987) 43.

3) K. Ohnishi and T. Murakami : Applications of Advanced Control Techniques, IEEE.Workshop on Microcomputer Control of Electric Drives, (A1), (1989) 1.

4) D. Purwanto, T. Murakami and K. Ohnishi : Positionvelocity-

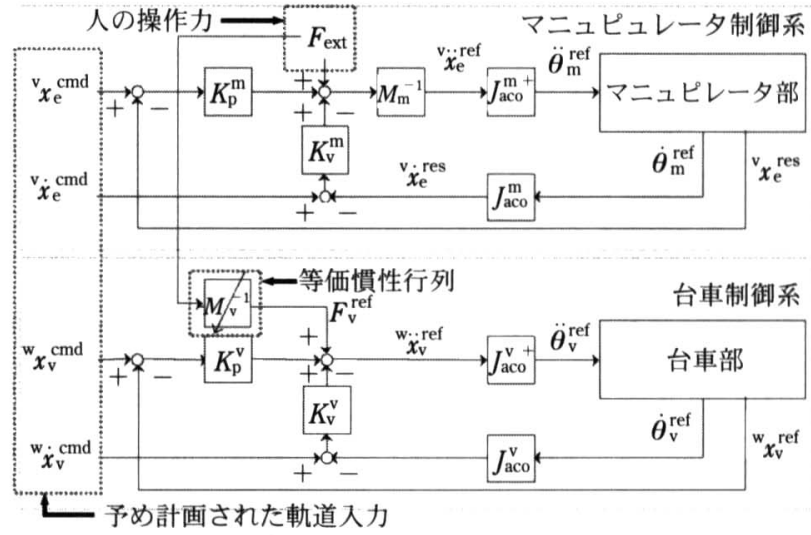

图 8 仮想インピーダンスモデルに基づいた人支援型移動マニピュ レータの制御

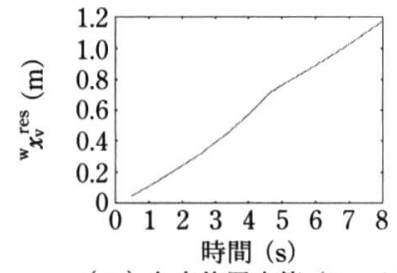

(a) 台車位置応答 ( $\mathrm{x}$-axis)

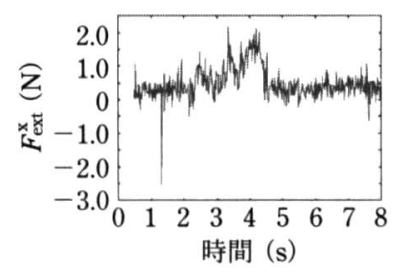

(c) 先端力応答 ( $\mathrm{x}$-axis)

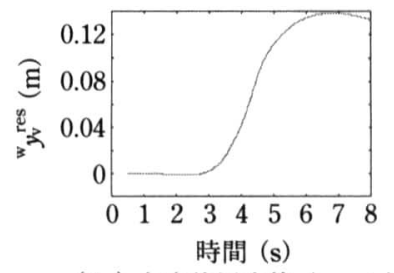

(b) 台車位置応答 ( $\mathrm{y}$-axis)

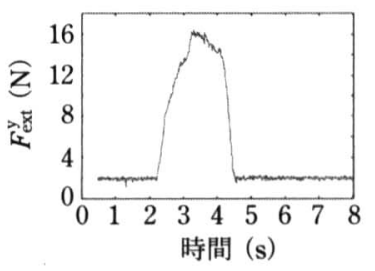

(d) 先端力応答 $(y$-axis
図 9 移動マニピュレータのコンプライアンス制御

based trajectory control for manipulator and its application to visual tracking system, A Publication of Industry Applications Society, The Transactions of The Institute of Electrical Engineers of Japan, 121-D, 8, (2001) 894.

5) T. Murakami, F. Yu and K. Ohnishi : Torque Sensorless Control in Multi-Degrees-of-Freedom Manipulator, IEEE. Trans. on Industrial Electronics, 40, 2, (1993) 259.

6) K. Kumeno, T. Murakamibilateral control and K.Ohnish : An Estimation of Slope for Mobile Manipulator, IEEE. International Conference on Advanced Motion Control (AMC2000), (2000) 104.

7) A. Inoue, et al. : Trajectory Control of an Human Cooperative Wheelchair Type Mobile Robot Using an Active Joystick, The 2002 Japan Industry Applications Society Conference (JIASC 2002), (2002) 715

8) E. Yamanaka, et al. : Motion Control of Mobile Manipulator for Human Interaction, The 28th Annual Conference of IEEE IES (IECONO 2), (2002) 2785 , 715 . 